\title{
IAMJ
}

INTERNATIONAL

AYURVEDIC

MEDICAL JOURNAL

ISSN: 23205091

Impact Factor: 5.344

\section{“A COMPARATIVE CLINICAL STUDY TO EVALUATE THE EFFICACY OF SHEETALA JALA NASYA AND MASHA TAILA NASYA WITH RASNADI GUGGULU IN THE MANAGEMENT OF AVABAHUKA WITH SPECIAL REFERENCE TO FROZEN SHOULDER"}

\author{
Maitradevi $^{1}$, Uma Patil $^{2}$ \\ ${ }^{1}$ Post Graduate Scholar, ${ }^{2}$ Associate Professor. \\ P.G Dept. of Kayachikitsa BLDEA's AVS Ayurveda Mahavidyalaya, Vijayapura, Karnataka, India.
}

Corresponding Author: maitrarameshhosmani@gmail.com

https://doi.org/10.46607/iamj1608102020

(Published Online: October 2020)

Open Access

(C) International Ayurvedic Medical Journal, India 2020

Article Received:22/09/2020 - Peer Reviewed:02/10/2020 - Accepted for Publication:04/10/2020

(D) Check for updates

\begin{abstract}
Avabahuka is a disease of Amsa Sandhi (shoulder joint) and it has been described under eighty types of Vata Vyadhi by Acharya Sushruta. Being a disease of shoulder joint, which has greatest range of motion, is of vital importance to the activities of daily routine work. This disease is a hindrance in one's productivity. Various effective treatment modalities have been mentioned in our classics regarding this disease. In order to reverse the pathogenesis, Shodhana is advised initially followed by Shamana therapies. In the present study 40 patients were selected incidentally and placed randomly into two groups- A and B, with 20 subjects in each group. Group- A received Nasya with Sheetala Jala and Group- B received Nasya with Masha Taila followed by Rasnadi Guggulu as Shamanoushadhi for both groups A and B. In both the groups after $7^{\text {th }}$ day of Nasya Karma follow up was done. Assessment was done on the bases of symptomatology. Nasya Karma provided highly significant results in all the symptoms of Avabahuka. In the present study as per the clinical data, 'Nasya with Masha Taila is found to be more effective than Nasya with Sheetala Jala'.
\end{abstract}


Keywords: Avabahuka, Nasya, Sheetala Jala, Masha Taila, Rasnadi Guggulu, Frozen Shoulder.

\section{INTRODUCTION}

The economy of the country lies on its work force. Avabahuka is one such disease that hampers the day to day activity of an individual. Amongst the category of diseases our Acharyas have considered Vata Vyadhis as an important entity. They have mentioned these Vata Vyadhis under the heading of Ashta Mahagadas $^{1}$, the disease Avabahuka is one among them, which is Vataja Nanatmaja Vyadhiªccording to some scholars and Vata Kapha Pradhana Vyadhi according to Madhava ${ }^{3}$.

Even though the term Avabahuka is not mentioned in the Vataja Nanatmaja Vyadhi, Acharya Sushruta ${ }^{4}$ and others have considered Avabahuka as a Vata Vyadhi. In Madhava Nidana ${ }^{5}$ two conditions of the disease has been mentioned- Amsa Shosha and Avabahuka.Amsa shosha can be considered as the Preliminary Stage of the disease where Loss or Dryness of Shleshaka Kapha at Amsa Sandhi occurs. In the next stage i.e. Avabahuka, due to the Loss of Shleshaka Kapha symptoms like Shoola during Movement, Bahu Praspanditahara i.e. Restricted Movements etc are manifested. While commenting on this, Vijayarakshita in his Madhukosha Teeka has mentioned that Amsa Shosha is produced by Shuddha Vata Janya and Avabahuka is Vata Kapha Janya. Avabahuka affecting the Amsa Moola exhibits the symptoms in Bahu.

Bahupraspanditahara $^{6}$ is the main Lakshana of Avabahuka associated with Shoola, Sthambha and Amsasosha.

According to Modern Science, this disease can be correlated with "Frozen shoulder" (adhesive capsulitis)", means a condition that cause Shoulder Pain with Restricted Movement even though there is no obvious Intrinsic Shoulder Disease. This may follow Bursitis or Tendonitis of the Shoulder or may be associated with systemic conditions such as Chronic Pulmonary Disease, MI, DM, or Prolonged Immobility of the Arm favours development of Adhesive Capsulitis. This condition is more common in Women after the age of 50 years, and in DM patients. It is though that $3 \%$ of people will develop the condition in their life- time. In the realm of conventional medicine this illness is managed by Analgesics, Physiotherapy, Oral Corticosteroids, Intra Articular Corticosteroid Injections, Capsular Distention, and Manipulation under Anaesthesia and Arthoscopic Capsular Release.

In our Science Vata Vyadhis can be relieved by therapies like Abhyanga, Swedana, Snehapana, Nasya Karma, Vasti Karma and Shamana Oushadhi Prayoga etc. Chikitsa sutra of Avabahuka includes Nasya ${ }^{8}$ Uttarabhouktika Snehapaana ${ }^{9}$, Naasaapana $^{10}$, Shamanaushadhi Prayoga etc. The drugs that are capable of resolving the Samprapti of Avabahuka are advocated. Hence considering all these factors the following study is undertaken to evaluate the Clinical Efficacy of the Sheetala Jala Nasya and Masha Taila Nasya with Rasnadi Guggulu in the management of Avabahuka.

\section{Materials and Methods:}

Materials: The following Materials were utilized for clinical trial:

Sheetala Jala ${ }^{11}$, Mashataila ${ }^{12}$, Rasnadi Guggulu ${ }^{13}$, Goniometer ${ }^{14}$

\section{Methods:}

Source of Data: It is a clinical study on the management of Avabahuka and the patients attending the OPD and IPD of B.L.D.E.A's AVS Ayurveda Mahavidyalaya Hospital and Research Centre, Vijayapura were taken for the study.

\section{Methods of Data Collection:}

1. Literary Source: This source was collected from Classical texts, Modern texts, and Published articles in reputed journals and from Website.

2. Clinical Source: Patients suffering from Avabahu$k a$ were randomly selected from OPD and IPD of B.L.D.E. A's AVS Ayurveda Mahavidyalaya Hospital and Research Centre, Vijayapura. Special camps were conducted, and patients were registered for study.

3. Drug Source: Raw drugs were collected from market and authenticated by Department of Dravyaguna, and the formulations were prepared in the department of Rasashastra and Bhaisajya Kalpana, B.L.D.E.A's 
AVS Ayurveda Mahavidyalaya Hospital and Research Centre, Vijayapura

Sample Size: Total 40 patients were subjected to the present clinical study

Study Design: It is an Open, Random Sampling, and Comparative Clinical Trail. Total 40 patients were divided in two groups A \& B having 20 patients in each group

\section{Inclusion Criteria:}

1. Patients presenting with clinical features of Avabahuka [Frozen shoulder]

2. Patients with either Sex

3. Patients with the age group of 16-60 years

4. Patients fit for Nasya.

5. Diabetic patients are also included.

6. Patients who agree for treatment.

\section{Exclusion Criteria:}

1. Patients with a history of fracture or dislocation of the affected hand

2. Patients associated with Systemic illness.

3. Pregnancy and Lactating women.

4. Age group below 16 and above 60 years.

5. Patients who are not fit for Nasya.

Method of examination of the patients: In this study the data was collected from the patients with the help of interview. The detailed data related to general history, history of past illness, present illness, family history, food habits, history of treatment taken so far etc, were recorded in the proforma of the case sheet. The systemic examination of the patients was also done, and findings were recorded as per the proforma.

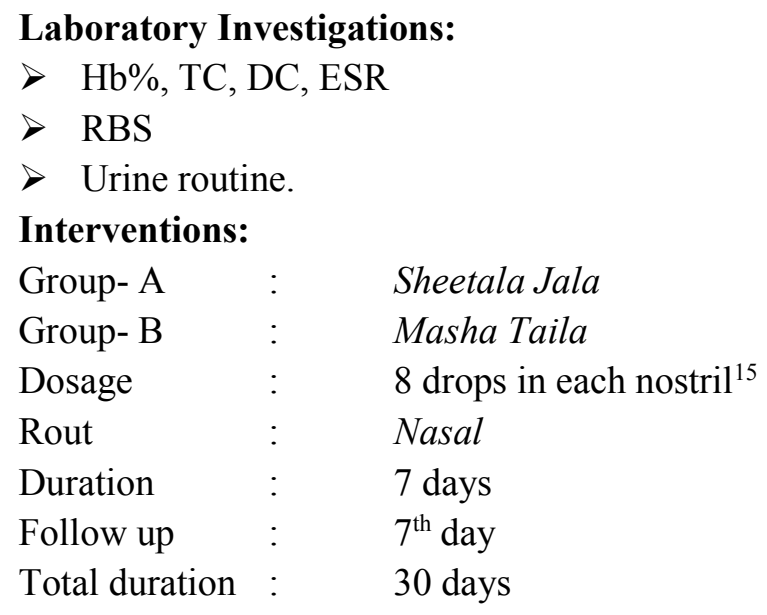

For Both the Groups: Rasnadi Guggulu

$\begin{array}{ll}\text { Dosage } & : 500 \mathrm{mg} \text { twice daily } \\ \text { Aushada Sevana Kala } & : \text { After Food } \\ \text { Route } & : \text { Oral } \\ \text { Anupana } & : \text { Ushnodaka } \\ \text { Duration } & : 21 \text { days } \\ \text { Follow up } & : 30 \text { days }\end{array}$

Nasya Karma:

Poorva Karma: Mukhabhyanga and Sthanika (shoulder joint) Abhyanga with Tilataila and Nadi Sweda were performed till Samyak Lakshanas were seen

Pradhana Karma: Nasya Karma (Marsha Nasya) was done with Sheetala Jala in Group A and Nasya Karma with Masha Taila in Group B.

Paschat Karma: Kavala and Gandusha were administered with Ushnajala.

Shamana: Rasnadi Guggulu 500mg twice daily with Ushnodaka.

\section{Assessment Criteria:}

Grading for Assessing Subjective and Objective Parameters: The improvement of patients was assessed on the basis of relief in the signs and symptoms of disease. To analyze the efficacy of the drug, marks were given statistically to each symptom. According to severity of the symptoms, the grading was given as below.

Subjective Parameters:

A) Main Symptoms:

1) Bahu Praspanditahara:

a) Can do Work Unaffectedly 0

b) Can do Strenuous Work with Difficulty -1

c) Can do Daily Routine Work with Great Difficulty - 2

d) Cannot do Any Work - 3

B) Associated Complaints:

1) Amsasandhi Shoola:

a) No Pain - 0

b) Mild Pain can do Strenuous Work with Difficulty-1

c) Moderate Pain can do Normal Work with Support-2

d) Severe Pain, Unable to do Work at All

2) Stambha

a) No stiffness $\quad-0$

b) Mild Stiffness can do routine Work $\quad-1$

c) Moderate Stiffness, can do Routine Work with Difficulty - 2

d) Severe Stiffness, Interfere with Routine Work -3 


\section{3) Amsa Shosha:}

a) No Wasting

b) Mild Wasting, can do Work -

c) Wasting Present, Work with Difficulty-

d) Wasting Present, cannot Move-

Objective Parameters:

1) Localized Swelling:

a) No Swelling -

b) Slight

c) Moderate -

d) Bulging beyond joint margins -

2) Tenderness (on Palpatation):

a) No Tenderness - 0

b) Patient Complains of Pain - 1

c) Patient Complains of Pain and Winces - 2

d) Patient Complains of Pain, Winces and Withdrew Joint -

3) Sandhi Graham (Goniometer Reading):

A) Forward Flexion:
a) Up to $180^{\circ}$
0
b) Up to $135^{\circ}$
1
c) Up to $90^{\circ}$
2
d) Up to $45^{0}$
3
e) Cannot Flex

B) Hyper Extension:
a) Up to $50^{\circ}$
0
b) Up to $30^{\circ}$
c) Up to $10^{\circ}$
2
d) Cannot Hyper Extense

\section{C) Abduction:}
a) Up to $180^{\circ}$
b) Up to $135^{0}$
c) Up to $90^{\circ}$
d) Up to $45^{0}$
e) Cannot Abduct

D) Internal Rotation:
a) Up to $90^{\circ}$
b) Up to $60^{\circ}$
0
c) Up to $30^{\circ}$
d) Cannot Rotate
E) External Rotation:
a) Up to $90^{\circ}$

b) Up to $60^{\circ}$ c) Up to $30^{\circ}$

2

d) Cannot Rotate

3

\section{Observations and Results:}

Effect of therapy on different Subjective parameters such as Bahupraspanditahara, Shoola, Stambha and Amsashosha, as well as Objective Parameters such as Swelling, Tenderness, Restriction of Shoulder joint movements (using Gonio meter) were examined and recorded before treatment, after $7^{\text {th }}$ day and after treatment and subjected to statistical analysis.

\section{Comparison of Effect of Treatment on:}

Bahu Praspanditahara: The results on the basis of Bahupraspanditahara in both the groups are statistically insignificant before treatment with $\mathrm{p}=0.1921$ and is highly significant after $7^{\text {th }}$ day with $\mathrm{p}=0.0024$ and after treatment with $\mathrm{p}=0.0004$. So, when we compared the mean values of both the groups it is observed that group $\mathrm{B}$ has more effect in reducing $\mathrm{Ba}$ hupraspanditahara as compared to Group A.

Shoola: The results on the basis of Shoola in both the groups are statistically insignificant before treatment with $p=0.4141$ and after $7^{\text {th }}$ day with $p=0.2763$ and is highly significant after treatment with $p=0.0042$. So, when we compared the mean values of both the groups it is observed that group B has more effect in reducing Shoola as compared to Group A.

Stambha: The results on the basis of Stambha in both the groups are statistically insignificant before treatment with $p=0.5224$ and after $7^{\text {th }}$ day with $p=0.2045$ and it is highly significant after treatment with $p=0.0011$. So, when we compared the mean values of both the groups it is observed that group B has more effect in reducing Stambha as compared to Group A.

Amsa Shosha: The results on the basis of Amsa Shosha in both groups are statistically insignificant before treatment with $\mathrm{p}=0.2319$, after $7^{\text {th }}$ day with $\mathrm{p}=0.8031$ and after treatment with $\mathrm{p}=0.5476$. So, when we compared the mean values of both the groups it is observed that group B has more effect in reducing Amsa Shosha as compared to Group A.

Localised Swelling: The results on the basis of Localised Swelling in both the groups are statistically insignificant before treatment with $\mathrm{p}=0.4317$, after $7^{\text {th }}$ day with $\mathrm{p}=0.5790$ and after treatment is completely 
cured. So, when we compared the mean values of both the groups it is observed that group B has more effect in reducing localised swelling as compared to Group A.

Tenderness: The results on the basis of Tenderness in both the groups are statistically insignificant before treatment with $\mathrm{p}=0.7620$ and after $7^{\text {th }}$ day with $\mathrm{p}=0.9891$ and is significant after treatment with $\mathrm{p}=0.4195$. So, when we compared the mean values of both the groups it is observed that group B has more effect in reducing Tenderness as compared to Group A.

Restriction of Forward Flexion: The results on the basis of Forward Flexion in both the groups are statistically insignificant before treatment with $\mathrm{p}=0.4710$ and is highly significant after $7^{\text {th }}$ day with $p=0.0233$ and after treatment with $\mathrm{p}=0.0398$. So, when we compared the mean values of both the groups it is observed that group B has more effect in reducing Forward Flexion as compared to Group A.

Restriction of Hyper Extension: The results on the basis of Hyper Extension in both the groups are statistically significant before treatment with $\mathrm{p}=0.3048$ and is insignificant after $7^{\text {th }}$ day with $\mathrm{p}=0.4198$ and after treatment with $\mathrm{p}=0.7512$. So, when we compared the mean values of both the groups it is observed that group B has more effect in reducing hyper extension as compared to Group A.

Restriction of Abduction: The results on the basis of Abduction in both the groups are statistically insignificant before treatment with $\mathrm{p}=0.1312$, after $7^{\text {th }}$ day with $\mathrm{p}=0.2340$ and after treatment with $\mathrm{p}=0.8366$. So, when we compared the mean values of both the groups it is observed that group B has more effect in reducing Abduction as compared to Group A.

Restriction of Internal Rotation: The results on the basis of Internal Rotation in both the Groups are statistically insignificant before treatment with $p=0.4201$ and after $7^{\text {th }}$ day with $\mathrm{p}=0.1196$ and is highly significant after treatment with $\mathrm{p}=0.0083$. So, when we compared the mean values of both the groups it is observed that group B has more effect in reducing internal Rotation as compared to Group A.
Restriction of External Rotation: The results on the basis of External Rotation in both the groups are statistically insignificant before treatment with $\mathrm{p}=0.9023$, after $7^{\text {th }}$ day with $\mathrm{p}=0.4193$ and after treatment with $p=0.2383$. So, when we compared the mean values of both the groups it is observed that group B has more effect in reducing external Rotation as compared to Group A.

\section{DISCUSSION}

Avabahuka is one among those Vatavyadhis, which results in Karmakshaya of Bahu. The specific Nidana of Avabahuku have not been separately mentioned. However, the Nidanas of Vatavyadhi in general may be considered as the Nidana. As per the symptomatology and pathogenesis of Avabahuka can be correlated to Frozen shoulder as said in modern science because of the presenting symptoms like Shoola (initial pain during freezing stage), Bahupraspanditahara (restricted range of movements of the shoulder joint), Stambha (stiffness) etc. The etiology is also similar like Ativyayama (excessive usage), Vishama Chesta (irregular movements) and Marmabhighata (any injury to the shoulder including tendinitis, bursitis, and rotator cuff injury)

According to Acharya Charaka, Vagbhata and Chikitsa Sara Sangraha advised to administer the Brumhana Nasya and Uttarabhaktika Snehapana in the management of Avabahuka. It is to overcome the Dhatukshayajanya Avabahuka and to combact the Vyanavata Dusthi. 'Bahoscha parivartanat 16, (movement of the shoulder) i.e. Rehabilitation of movements of shoulder joint is advised by Yogaratnakara to improve the movements and to avoid the recurrence of Avabahuka. The combined effect of Shodhana and Shamana would provide complete remission of the disease.

\section{Probable mode of action of Nasya Karma:}

Acharya Vagbhata's quotation "Naasa hi Shirasodwa$\mathrm{ram}^{17 \text { " }}$ states that, nose is the easiest and closest opening for conveying the potency of medicines to the cranial cavity. The Nasya Dravya acts by reaching 'Shringataka Marma' from where it spreads into various Srotas (vessels and nerves) and brings out vitiated 
Dosha from the head. Acharya Sushruta considers Shringhataka Marma as a Sira and Sadyopranahara Marma and as a composite structure consisting of four Siras in connection with four sense organs- viz, Nose, Ear, Eye and Tongue.

The Entry of Drugs into the Brain can be understood by the following 3 concepts:

The absorption is carried out in 3 media. They are.

1. By general blood circulation after absorption through mucous membrane.

2. The direct pooling into venous sinuses of brain via inferior ophthalmic veins.

3. Absorption directly into the cerebrospinal fluid.

The nasal cavity directly opens into frontal, maxillary and sphenoidal air sinuses. Epithelial layer is also continuous throughout the length. The momentary retention of drug in nasopharynx and suction causes oozing of drug material into air sinuses. These sites have rich blood vessels entering the brain and meninges through the existing foramens in the bones. Therefore, there are better chances of drug transportation in this path. The Shringhataka Marma has been explained by recent authors as middle cephalic fossa of the skull consisting para nasal sinuses, meningeal vessels and nerves. One can see into the truth of narration made by Acharya Vagbhata here -the drug administered enters the para nasal sinuses. That is Shringhataka where the ophthalmic veins and other veins spread out. The sphenoidal sinuses are in close relation with intra cranial structures. The mentioning of the Shringhataka in this context seems to be more reasonable.

The action of Nasya Karma depends upon the Dravya used in it. Based on these, it is divided into Shodhana, Shamana and Brumhana. Here in this study "Brumhana Nasya" was administered. It provides nourishment to Shiro-Indriya and other organs thereby alleviates the vitiated Vata. Hence, it is useful in Vatajanya ailments.

\section{Mechanism of Drug Absorption:}

The first step in the absorption of drug from the nasal cavity is passage through the mucus. Small, unchanged particles easily pass through this layer. However, large or changed particles may find it more difficult to cross.
Several mechanisms have been proposed but the following two mechanisms have been considered predominantly.

$>$ The first mechanism involves an Aqueous Route of transport, which is also known as the paracellular route: This route is slow and passive. There is an inverse log-log correlation between intranasal absorption and the molecular weight of watersoluble compounds. Poor bioavailability was observed for drugs with a molecular weight greater than 1000 Daltons.

$>$ The second mechanism involves transport through a Lipoidal Route that is also known as the transcellular process and is responsible for the transport of lipophilic drugs that show a rate dependency on their liphophilicity. Drugs also cross cell membranes by an active transport route via carrier-mediated means through the opening of tight junctions.

\section{Physic-chemical properties of drug:}

$>$ Lipophilicity: Lipophilic drugs have better absorptive capacity. Because lipid soluble substance has greater chance of passive absorption directly capillaries and veins.

$>$ Viscosity: Formulation with higher viscosity increases the absorption of the drug by increasing the contact time to the nasal mucosa. The absorption of the Sneha Nasya is further supplemented by its viscous nature.

$>$ pH: $\mathrm{pH}$ of the drug plays important role in absorption of drug through nasal route. The $\mathrm{pH}$ formulation should be within 5.5-6.5 to get greater permeation.

$>$ Molecular weight: Low molecular weight drugs are rapidly absorbed through nasal mucosa due to high permeability, fairly wide absorption area, porous and thin endothelial basement membrane of the nasal epithelium. Absorption decreases significantly if the molecular weight is greater than 1000 daltons.

Masha Taila: Myelin sheath is the first covering of nerve fibre which is composed of lipid material. Blood-brain barrier is highly permeable for lipid substances, and substances which are fat-soluble. There- 
fore, these substances can pass easily through the blood-brain barrier and exert their action. The lipid contents of "Masha Taila" may pass through the blood -brain barrier easily due to its transport, some of the active principles may reach up to certain levels in the nervous system and helps in removing the irritation. It may act as an anti-inflammatory agent also. On its nasal administration, it reaches the Shirogata Indriyas to cause Vatashamana and Brumhana. To conclude, Nasya Karma with Mashataila helps in Avabahuka by its Vatashamana and Brumhana Karma.

Sheetala Jala: According to Acharya Sushruta ${ }^{18}$, Antariksha Jala is of Anirdishya Rasa, equal to Amruta Guna's, and it acts as Jeevanam, Tarpanam, Dhaaranam, Aashwasajananam, and it relieves Shrama, Pipasa, Mada, Murcha, Tandra, Nidra and Daha and is absolutely the Pathyam (most wholesome for health). Acharya Charaka ${ }^{19}$ said that Aindra Jala has by nature Sheetam, Suchi, Shivam (Wholesome), Mrushtam (palatable), Vimalam (clean) and Laghu Gunas. Naturally Sheetala Jala has properties like Madhura Rasa, Madhura Vipaka, Guru Guna, Balya, Brumhana, Tarpana and Dharana etc. all these properties of Sheetala Jala leads to Vatashamaka.

So, on the basis of these Gunas it can be said that Sheetala Jala Nasya also having Brumhana Properties. Because of this Acharya Bhavaprakasha ${ }^{20}$ highlighted the treatment of Nasya with Sheetala Jala followed by Guggulu and said as these together act as 'Supreme Medicine (Paramoushadha)' in treating Avabahuka, Manyastambha and Urdhwajatru Vikaras etc.

In the present study Distilled water is taken as Sheetala Jala for Nasya. As Nasya Procedure is one among the Major Panchakarma procedure it aquires special attention regarding the use of Nasya Dravya. To prevent Nasya Vyapat's and also for the safety of the patient purpose I have used distilled water as it is purest and safest water for medicinal purpose. Distilled water ${ }^{21}$ is the purest form of water, it promotes the natural detoxification of organs (can be correlated with Amadoshahara), improves digestion (as $A g$ nimandhya is the one of reason for manifestation of disease). So that Samprapti Vighatana can be achieved.

$\mathrm{pH}$ of distilled water is 5.8 almost nearer to $\mathrm{pH}$ of nasal mucosa (5.5-6.5) and molecular weight (18.02 dalton) is also within the normal weight i.e.less than 1000 dalton. So distilled water showed effect during process. As lipophilic drugs have better absorption capacity as compared to non-lipophilic drugs because of lower viscosity leads to lesser absorption and permeation of drug through mucosa. So, it can be concluded as because of less absorption of permeation of Sheetala Jala as it is having lesser viscisity, and nonlipophilic media, is not better than Masha Taila in treating Avabahuka proved null hypothesis

Rasnadi Guggulu: It is a synergistic combination of Vatahara drugs like Rasna, Guduchi, Eranda, Devadaru, Shunthi and Guggulu. Most of the drug contained in Rasnadi Guggulu has properties like $\mathrm{Va}$ takaphanashaka, Deepana, Balya, Rasayana, Threedoshanashaka, Pachana, Shothaghna, Vedanasthapana, Rechana and Shoolaprashamana. These are likely to breakdown the pathogenesis of Avabahuka, and thus may arrest the progress of the disease.

During the Procedure of Nasya there is significant effect was observed in Group A. This may be due to the effect of Abhynaga and Swedana during procedure of Nasya or it may act as Placebo during Nasya. But after treatment there is no significant effect was observed. It may be due to the altered properties of Sheetala Jala and Distilled water. In group B there was highly significant effect was observed during treatment and after treatment also.

So, Clinically Group B is more effective than Group A because all the tested parameters statistically show good improvement for the patients in Group B when compared to Group A

\section{CONCLUSION}

In present study as per the clinical data, Nasya with Sheetala Jala has no significant effect in the management of Avabahuka, but Nasya with Masha Taila has more significant effect in the management of Avabahuka. Nasya Karma has significant effect in relieving 
most of the symptoms of Avabahuka. In present study, Nasya with Sheetala Jala during procedure may acts as Placebo in the management of Avabahuka. For the purpose of safety as it is Nasya Karma in this study I have taken distilled water as it is the only water that can be taken into the body without any damage to the tissues.

The combined effect of Masha Taila and Rasnadi Guggulu (Shamanoushadhi) helps in relieving the disease due to its Brumhana, and Vatahara properties. Thus, this dissertation work is presented with the trust that the observations and results may strengthen the scope of further research advancement in this aspect of Ayurvedic medicine, for the betterment of mankind.

\section{REFERENCES}

1. Shukla V, Tripathi R. Charaka Samhita (Vol I). Varanasi: Ckowkhamba Sanskrit Pratisthan; 2009,

2. Kaviraj Kunjala Bhishagratna. Sushruta Samhita (Vol I). $3^{\text {rd }}$ Ed. Varanasi: Chowkhamba Sanskrit Series; 2005,

3. Dr. P. Himasagara Chandra Murthy. Madhukosha's Madhavanidhana (Vol I). Varanasi: Chowkhamba Sankrit Series; 2006.

4. Kaviraj Kunjala Bhishagratna. Sushruta Samhita (Vol I). $3^{\text {rd }}$ Ed. Varanasi: Chowkhamba Sanskrit Series; 2005,

5. Dr. P. Himasagara Chandra Murthy. Madhukosha's Madhavanidhana (Vol I). Varanasi: Chowkhamba Sankrit Series; 2006.

6. Prof. K. R. Srikantha Murthy. Vagbhata's Astanga Hrdayam (Vol II). Varanasi: Chowkhamba Krishnadas Academy; 2006.

7. John Crawford Adams, David. L. Humble-Outlining Of Orthopaedics, Churchil Livingstone, 13 Ed

8. Prof. K. R. Srikantha Murthy. Vagbhata's Astanga Hrdayam (Vol II). Varanasi: Chowkhamba Krishnadas Academy; 2006.

9. Shukla V, Tripathi R. Charaka Samhita (Vol II). Varanasi: Ckowkhamba Sanskrit Pratisthan; 2010,

10. Priya Vrat Sharma. Chakradatta. Sanskrit With English Translation. $3^{\text {rd }}$ Ed; Varanasi; Chowkhamba Bharati Academy. 2002

11. Bhavamishra's. Bhavaprakasha (Part II). $11^{\text {th }}$ Ed. Varanasi: Chowkhamba Sanskrit Bhawan; 2007.

12. Shri Govind Dasji S. Bhaisajya Ratnavali (Vol II). 1st Ed. Varanasi: Chowkhamba Sanskrit Bhawan; 2006
13. Dr. Madham Shetty Suresh Babu. Yoga Ratnakara (Vol I). $2^{\text {nd }}$ Ed. Varanasi: Chowkhamba Krishnadas Academy; 2011

14. www.wikipedia.com.

15. Prof. K. R. Srikantha Murthy. Vagbhata's Astanga Hrdayam (Vol I). Varanasi: Chowkhamba Krishnadas Academy; 2007.

16. Dr. Madham Shetty Suresh Babu. Yoga Ratnakara (Vol I). $2^{\text {nd }}$ Ed. Varanasi: Chowkhamba Krishnadas Academy; 2011.

17. Prof. K. R. Srikantha Murthy. Vagbhata's Astanga Hrdayam (Vol I). Varanasi: Chowkhamba Krishnadas Academy; 2007.

18. Kaviraj Kunjala Bhishagratna. Sushruta Samhita (Vol I). $3^{\text {rd }}$ Ed. Varanasi: Chowkhamba Sanskrit Series; 2005.

19. Shukla V, Tripathi R. Charaka Samhita (Vol I). Varanasi: Ckowkhamba Sanskrit Pratisthan; 2009.

20. Bhavamishra's. Bhavaprakasha (Vol I). $11^{\text {th }}$ Ed. Varanasi: Chowkhamba Sanskrit Bhawan; 2007.

21. classifieds.usatoday.com

\section{Source of Support: Nil \\ Conflict of Interest: None Declared}

How to cite this URL: Maitradevi \& Uma Patil: A Comparative Clinical Study To Evaluate The Efficacy Of Sheetala Jala Nasya And Masha Taila Nasya With Rasnadi Guggulu In The Management Of Avabahuka With Special Reference To Frozen Shoulder. International Ayurvedic Medical Journal \{online\} 2020 \{cited October, 2020\} Available from: http://www.iamj.in/posts/images/upload/4669 4676.pdf 